\title{
Microbiological status of some commonly available food items and the effects of microwave oven heat on the existence microflora
}

\author{
${ }^{1}$ Islam, M.F., ${ }^{1}$ Nur, I.T., ${ }^{1}$ Islam, T., ${ }^{1}$ Sultana, R., ${ }^{2}$ Rezanujjaman, Md. and ${ }^{2, *}$ Acharjee, M. \\ ${ }^{1}$ Department of Microbiology, Stamford University Bangladesh, 51 Siddeswari Road, Dhaka-1217, \\ Bangladesh \\ ${ }^{2}$ Department of Molecular and Developmental Biology, Graduate School of Science and Technology, \\ Shizuoka University, Oya 836, Suruga-ku, Shizuoka, 422-8529, Japan
}

\begin{abstract}
Article history:
Received: 9 November 2019

Received in revised form: 24

November 2019

Accepted: 26 November 2019

Available Online: 22

December 2019
\end{abstract}

Keywords:

Ready to eat food,

Microbial contamination,

Microwave oven heat,

Drug-resistant

DOI:

https://doi.org/10.26656/fr.2017.4(3).376

\begin{abstract}
Foods are the major source of energy and nutrition for all the living organisms. Measuring food safety and security is a vital concern nowadays. The present study attempted to evaluate a complete microbiological profile of some popular food items collected from different restaurants along with their drug-resistant profile. The main focus of this study was to evaluate the efficacy of 60 seconds microwave oven heat on the growth of microorganisms present in the collected food items. Presence of bacterial and fungal microbiological profiling of the food items and their drug-resistant pattern were determined through conventional cultural, biochemical and Kirby Bauer methods. After that, the food was heated in the microwave oven for 60 seconds. All the food items (chicken sandwich, French pizza, chicken pie, pasta, hot dog) were found to be highly contaminated with total viable bacteria and fungus up to $10^{7} \mathrm{CFU} / \mathrm{g}$ while the pathogenic bacteria such as Escherichia coli, Staphylococcus spp., Pseudomonas spp. was estimated up to $10^{6} \mathrm{CFU} / \mathrm{g}$. After 60 -second microwave oven heat treatment, the existence microbial load was significantly reduced. Meanwhile, fecal coliform was only detected in chicken sandwich before the heat treatment $\left(10^{2} \mathrm{CFU} / \mathrm{g}\right)$ but that was completely eliminated by heat treatment. Staphylococcus spp. and Pseudomonas spp. were found in untreated chicken pie, pasta and French pizza samples although after heat treatment the growth was $100 \%$ eliminated. Only in chicken sandwich, 2-log reduction of Staphylococcus spp. was notified after 60 -second heat. Moreover, the identified bacteria were found to be $100 \%$ resistant against commonly used antibiotics but only streptomycin $(10 \mu \mathrm{g})$, azithromycin $(15 \mu \mathrm{g})$ and gentamycin $(10 \mu \mathrm{g})$ were found as effective drugs against all the isolates. The presence of resistant strain in food is very alarming which indicates the poor management set up and lack of proper legislation in food sector. However, the 60 -second microwave oven heat treatment was so effective to reduce the substantial amount of bacteria.
\end{abstract}

\section{Introduction}

For the maintenance of healthy life, feasting good and safe food has no alternative in our daily lifestyle (Rahman and Noor, 2012; Noor et al., 2013; Acharjee, Fatema, Jahan et al., 2013; Acharjee, Jahan, Rahman et al., 2013; Jane et al., 2018). As foods are the major source of energy and nutrition for all the living organisms including human, animal and even plants, therefore, measuring the food safety and security is the vital concern nowadays (Rahman and Noor, 2012; Acharjee, Fatema, Jahan et al., 2013). There are several reasons such as physical, chemical and biological matters behind the vigorous deterioration of the quality of different food and food products (Balbani and
Montovani, 2012). Among these three factors of food spoilage, biological matters are so serious as because of the direct involvement of pathogenic microorganisms which are mainly responsible for food borne intoxication and infection (CDC, 2014). As explained in many previous studies that the common food borne pathogens are Campylobacter spp., E. coli, Listeria monocytogenes, Salmonella spp. and Staphylococcus spp. (FSANZ 2001a; FSANZ 2001b; FAO 2004). However, several methods are available in modern decades to eradicate the dissemination of food born microorganisms such as irradiation, cooking, drying, pasteurization, microwave heating and even adding of preservatives during the food preparation (Hossain et al., 2019). 
Many studies previously reported that the gamma irradiation with different doses (3, 4, 6 and 8 Kilo Gray) have considered a very useful method to inhibit the excessive growth of bacteria in raw fish and meat sample (Acharjee, Fatema, Jahan et al., 2013; Acharjee, Israt and Noor, 2019; Acharjee, Sultana and Noor, 2019). Another study focused on the role of drying and cooking process on the bacterial proliferation during food preparation (Nur et al., 2019). The most common source of radiation is microwave-operating devices including radars, electric oven and diathermy (Balbani and Montovani, 2012). Meanwhile, short time microwave oven heating (60-second) process is now very common not only in the megacity of Bangladesh but also very popular in all over the world especially for the ready to eat food preparation (Hossain et al., 2019). Earlier studies revealed that the few second heat treatments are much quicker and easier methods to reduce the growth of food born microorganisms than the other conventional heating process (Cross and Fung, 1982; Rosenberg and Bogl, 1987; Kakita et al., 1995; Canumir et al., 2002). Thus, one of the common factors is still making controversy among the scientists about the thermal effects and the non-thermal effects of radiation (Dreyfuss and Chipley, 1980; Welt et al., 1994; Wayland et al., 1997; Kothari et al., 2011; Trivedi et al., 2011). Microorganisms can be killed using the thermal effect of microwave radiation while non-thermal effect has been suggested to inactivate microbial propagation (Jeng et al., 1987; Barnabas et al., 2011; Woo et al., 2000). Dissemination of drug-resistant bacteria through spoilage food is now very common issue in many developing countries, which may create massive obstacle in disease medication (Dutta et al., 2013).

Along these lines, the present study attempted to (1) introduce the microbiological profiling of some common ready to eat food, (2) the drug-resistant attributes of the isolates and (3) the effects of 60 seconds microwave oven heat treatment on food microflora.

\section{Materials and methods}

2.1 Study area, sampling, sample processing and microbiological analysis

A total of five samples of each food type (chicken sandwich, French pizza, chicken pie, pasta and hot dog) $(\mathrm{n}=25)$ was randomly collected following the standard protocol of APHA (1998). All the samples were transported to the laboratory as soon as possible for microbiological assay. Samples were divided equally into two portions. The first portion was assessed without microwave oven heat treatment while the other portion was assessed after microwave oven heat treatment.
A total of $10 \mathrm{~g}$ of each sample portion was homogenized with $90 \mathrm{~mL}$ of buffered peptone water $\mathrm{pH}$ $7.2 \pm 0.2$ ) in 9: 1 ratio and serially diluted up to $10^{-3}$. From the $10^{-2}$ dilution, $0.1 \mathrm{~mL}$ was introduced on to the nutrient agar and Sabouraud dextrose agar for the isolation of total viable bacteria and fungi, respectively. Subsequently, MacConkey agar, Mannitol Salt agar Salmonella Shigella agar and Cetrimide agar were used as selective media for the quantification of coliforms, Staphylococcus spp., Pseudomonas spp. consecutively (Cappuccino and Sherman, 1996; Acharjee et al., 2014). All the inoculated plates were incubated at $37^{\circ} \mathrm{C}$ for 24 hours except SDA plates, which were incubated at $25^{\circ} \mathrm{C}$ for 48 hours.

\subsection{Biochemical identification of the isolates}

The biochemical properties of identified isolates were confirmed through standard biochemical methods (Cappuccino and Sherman, 1996).

\subsection{Antibiotic susceptibility test of the identified bacteria}

The pathogenic isolates were examined for the detection of antibiotic susceptibility traits (either drugresistant or sensitive) by disc diffusion assay on MuellerHinton agar (Difco, Detroit, MI) against commonly used antibiotics by following the standard protocol (Bauer et al., 1966; Ferraro et al., 2011). Lawns of bacterial suspensions including Escherichia coli, Pseudomonas spp., and Staphylococcus spp. (turbidity compared with the McFarland standard $\left.\mathrm{OD}_{600}-0.5\right)$ were prepared and introduced on to Muller Hinton agar. Some common antibiotics such as Kanamycin (30 $\mu \mathrm{g})$, Streptomycin (10 $\mu \mathrm{g})$, Gentamycin $(10 \mu \mathrm{g})$, Azythromycin (15 $\mu \mathrm{g})$, Tetracycline $(30 \mu \mathrm{g})$ were introduced against the targeted bacteria. All the plates were incubated at $37{ }^{\circ} \mathrm{C}$ for $12-18$ hrs and examined for formation of the zone of inhibitions (mm).

\section{Results and discussion}

Propagation of different pathogenic strains including coliform and fecal coliform in food samples due to the poor sanitation and hygienic condition are the main causative agent of several food borne diseases like diarrhea and dysentery (Mead et al., 1999; Munshi et al., 2012; Tamang et al., 2016). Such diseases are very common in developing countries like Bangladesh due to the lack of proper knowledge on personnel hygiene as well as poor maintenance quality of raw materials (Tamag et al., 2011, Acharjee, Jahan, Rahman et al., 2013).

3.1. Microbiological quality analysis of the samples and the effects of 60-second microwave oven heat treatment 
All the street food items (chicken sandwich, French pizza, chicken pie, pasta, hot dog) were highly contaminated with various pathogenic microorganisms such as E. coli, Staphylococcus spp, and Pseudomonas spp. before and after heat treatment (Figure 1). However, the presence of $E$. coli was noticed only in chicken sandwich before the heat treatment $\left(10^{2} \mathrm{CFU} / \mathrm{g}\right)$ and the growth was totally eradicated after post heat treatment. Due to heat treatment, the total viable bacteria both in chicken sandwich and french pizza was observed to reduce up to $5 \log$. Whereas $6 \log$ reductions of total viable bacteria were found in chicken pie but $2 \mathrm{log}$ reduction was notified in pasta after heat treatment. On the contrary, the fungal growth was deducted about 1 $\log , 2 \log , 3 \log$ and $4 \log$ in the post-heat samples of chicken pie, french pizza, pasta and chicken sandwich respectively (Figure 1). Though Staphylococcus spp. and Pseudomonas spp. were found in pre-heat sample of chicken pie, pasta and french pizza, the heat treatment was able to completely eliminate them but only in chicken sandwich 2 log reduction of Staphylococcus spp. was notified. Couples of previous studies investigated that the existence of contaminating microflora in food samples may occur during the processing of raw material, mixing of ingredients and packaging of the end products (Anon., 2000; FSANZ, 2001a; FSANZ, 2001b; Anon., 2003; Anon., 2004; Anon., 2006). According to the International Commission on Microbiological Specifications for Foods (ICMSF) 1986 the presence of a specific pathogen in food should not be exceed $10^{2} \mathrm{CFU} /$ g. In this study, maximum post-heated food harbored excessive amount of pathogens which exited the marginal limit provided by International Commission on Microbiological Specifications for Foods (ICMSF) 1986. However, the presence of fecal coliform, colifrom and other pathogens in different food samples are the principle reason of food borne diseases (Acharjee, Fatema, Jahan et al., 2013). So, proper methodology including microbial load reduction method should be used to eliminate the contamination of this microflora.

\subsection{Biochemistry of the isolates}

A total of five types of isolates showed their physiological properties through several biochemicals tests and confirmed the pathogens (Table 1).
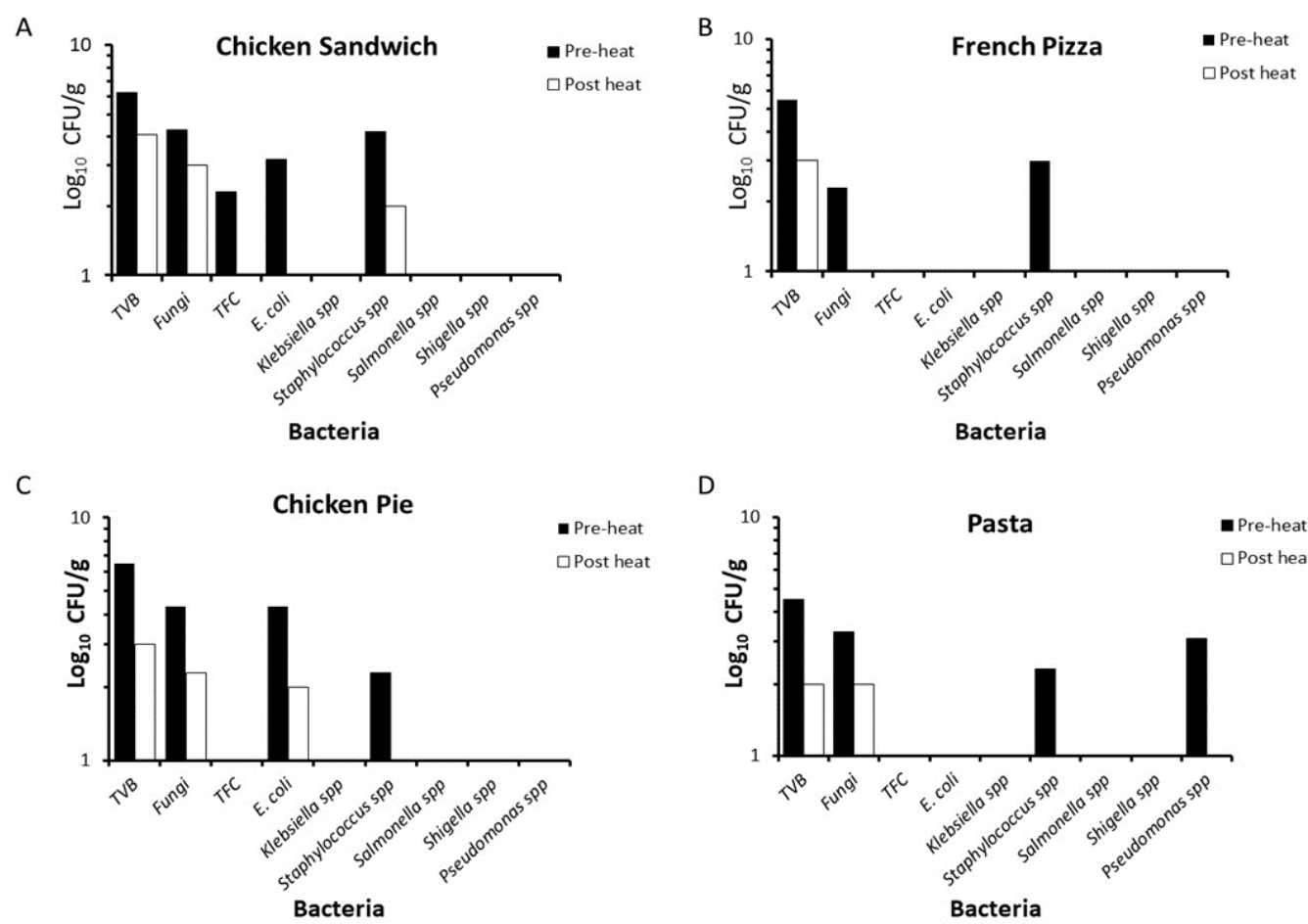

D

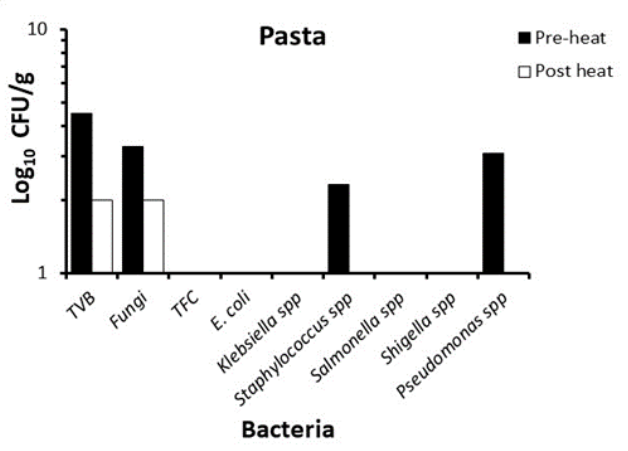

$\mathrm{E}$

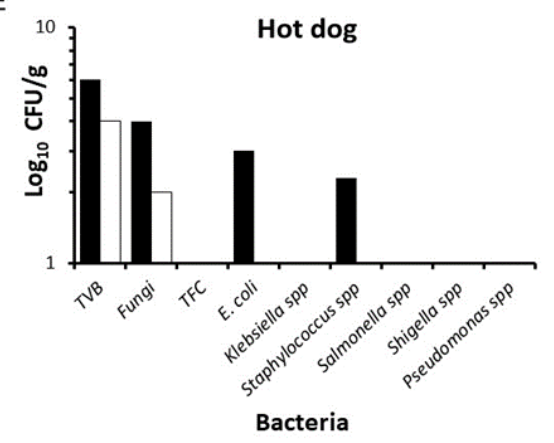

- Pre-heat

$\square$ Post heat 
Table 1. Biochemical identification of the pathogens isolated from different ready-to-eat food items

\begin{tabular}{|c|c|c|c|c|c|c|c|c|c|c|}
\hline \multirow{2}{*}{ Isolated Strain } & \multicolumn{3}{|c|}{ TSI } & \multirow{2}{*}{$\begin{array}{c}\mathrm{H}_{2} \mathrm{~S} \\
\text { reaction }\end{array}$} & \multirow{2}{*}{ Indole Test } & \multirow{2}{*}{ MR Test } & \multirow{2}{*}{ VP Test } & \multirow{2}{*}{ Citrate Test } & \multirow{2}{*}{$\begin{array}{c}\text { Motility } \\
\text { Test }\end{array}$} & \multirow{2}{*}{$\begin{array}{c}\text { Oxidase } \\
\text { Test }\end{array}$} \\
\hline & Slant & Butt & Gas & & & & & & & \\
\hline E. coli & $\mathrm{Y}$ & $\mathrm{Y}$ & + & - & - & + & - & - & + & - \\
\hline Staphylococcus spp. & $\mathrm{Y}$ & $\mathrm{R}$ & + & + & - & + & - & + & + & - \\
\hline Pseudomonas spp. & $\mathrm{R}$ & $\mathrm{R}$ & - & - & - & - & - & + & + & + \\
\hline
\end{tabular}

The experiments were conducted three times independently, and the results were found to be reproducible. One representative data has been shown. TSI: Triple Sugar Iron Test, Y: Yellow (Acid), R: Red (Alkaline), MR: Methyl red, VP: Voges-Proskauer

Table 2. Antibacterial susceptibility test of the isolates

\begin{tabular}{|c|c|c|c|c|c|c|c|}
\hline \multirow{3}{*}{ Antibiotic } & \multicolumn{7}{|c|}{ Isolates } \\
\hline & \multirow{2}{*}{ Disc Content } & \multicolumn{2}{|c|}{ E. $\operatorname{coli}(\mathrm{n}=3)$} & \multicolumn{2}{|c|}{ Staphylococcus spp. $(\mathrm{n}=5)$} & \multicolumn{2}{|c|}{ Pseudomonas spp. $(\mathrm{n}=1)$} \\
\hline & & $\mathrm{R}(\%)$ & $\mathrm{S}(\%)$ & $\mathrm{R}(\%)$ & $\mathrm{S}(\%)$ & $\mathrm{R}(\%)$ & $\mathrm{S}(\%)$ \\
\hline Polymyxin B & 300 units & 0 & 100 & 0 & 100 & 0 & 0 \\
\hline Kanamycin & $30 \mu \mathrm{g}$ & 0 & 100 & 100 & 0 & 100 & 0 \\
\hline Methicillin & $30 \mu \mathrm{g}$ & 0 & 100 & 100 & 0 & 0 & 100 \\
\hline Streptomycin & $10 \mu \mathrm{g}$ & 0 & 100 & 0 & 100 & 0 & 100 \\
\hline Vancomycin & $30 \mu \mathrm{g}$ & 100 & 0 & 100 & 0 & 0 & 100 \\
\hline Gentamycin & $10 \mu \mathrm{g}$ & 0 & 100 & 0 & 100 & 0 & 100 \\
\hline Nalidixic acid & $30 \mu \mathrm{g}$ & 0 & 100 & 100 & 0 & 0 & 100 \\
\hline Azithromycin & $15 \mu \mathrm{g}$ & 0 & 100 & 100 & 0 & 100 & 0 \\
\hline Penicillin G & $10 \mu \mathrm{g}$ & 100 & 0 & 100 & 0 & 100 & 0 \\
\hline Erythromycin & $15 \mu \mathrm{g}$ & 0 & 100 & 100 & 0 & 100 & 0 \\
\hline Amoxicillin & $30 \mu \mathrm{g}$ & 100 & 0 & 100 & 0 & 100 & 0 \\
\hline Ceftriaxone & $30 \mu \mathrm{g}$ & 100 & 0 & 100 & 0 & 100 & 0 \\
\hline Ciprofloxacin & $5 \mu \mathrm{g}$ & 100 & 0 & 0 & 100 & 100 & 0 \\
\hline Ampicillin & $10 \mu \mathrm{g}$ & 100 & 0 & 100 & 0 & 100 & 0 \\
\hline Tetracycline & $30 \mu \mathrm{g}$ & 100 & 0 & 100 & 0 & 100 & 0 \\
\hline Chloramphenicol & $30 \mu \mathrm{g}$ & 100 & 0 & 100 & 0 & 0 & 100 \\
\hline Cefixime & $5 \mu \mathrm{g}$ & 0 & 100 & 100 & 0 & 100 & 0 \\
\hline
\end{tabular}

R: Resistant, S: Sensitive

\subsection{Detection of the drug-resistant bacteria in the samples of before heat treatment.}

To evaluate the efficacy of commonly available antibiotics as well as the clinical significance of the bacterial isolates, the present study introduced antibiotic susceptibility test. Identified bacterial isolates were experimented to determine the antibiotic susceptibility against the common antibiotics. All the isolates from the samples were found to be $100 \%$ sensitive against streptomycin $(10 \mu \mathrm{g})$, azithromycin $(15 \mu \mathrm{g})$ and gentamycin $(10 \mu \mathrm{g})$ while all the strains showed resistance against more than one antibiotics such as penicillin $\mathrm{G}(10 \mu \mathrm{g})$, erythromycin $(15 \mu \mathrm{g})$, amoxicillin (30 $\mu \mathrm{g})$, ceftriaxone $(30 \mu \mathrm{g})$, ciprofloxacin $(5 \mu \mathrm{g})$, ampicillin $(10 \mu \mathrm{g})$, tetracycline $(30 \mu \mathrm{g})$, chloramphenicol (30 $\mu \mathrm{g})$ and cefixime $(5 \mu \mathrm{g})$ (Table 2$)$. A number of research findings unveiled, the resistance gene can be transferred through contaminated food into the human body, which may hinder the disease medication (Bennett and Klich, 2008; Canteón, 2009; Acharjee, Fatema, Jahan et al., 2013).

\section{Conclusion}

Overall, the present investigation discussed the compact microbiological profile of some popular food items as well as their drug-resistant properties. Previously huge information has been gathered on the propagation of bacterial strain in different foods but unfortunately, very few studies described the methodology by which the existence pathogens might be reduced. This study showed the 60 seconds of heat treatment by microwave oven was so effective to reduce the substantial amount of bacteria. Moreover, the presence of resistant strain in food is very much alarming which indicates the poor management set up and lack of proper legislation in the food sector. In this perspective, the given information on the microbiological quality in accordance with the recommended microbiological criteria of different food items would impart a practical outcome in knowledge dissemination on food safety in Bangladesh.

\section{References}

Acharjee, M., Ahmed, E., Munshi, S.K. and Noor, R. (2014). Validation of $\gamma$-irradiation in controlling 
microorganisms in fish. Nutrition and Food Science, 44(3), 258-266. https://doi.org/10.1108/NFS-072013-0089

Acharjee, M., Fatema, K., Jahan, F., Siddique, S.J., Uddin, M.A. and Noor, R. (2013). Prevalence of Vibrio cholerae in different food samples in the city of Dhaka, Bangladesh. International Food Research Journal, 20(2), 1017-1022.

Acharjee, M., Israt, I. and Noor, R. (2019). Effects of gamma irradiation on the propagation of microbial growth in commonly available meat in Bangladesh. International Food Research Journal, 26(4), 12111218.

Acharjee, M., Jahan, F., Rahman, F. and Noor, R. (2013). Bacterial proliferation in municipal water supplied in mirpur locality of Dhaka city, Bangladesh. Clean - Soil, Air, Water, 42(4), 434441. https://doi.org/10.1002/clen.201200618

Acharjee, M., Sultana, R. and Noor, R. (2019). Consequences of $\gamma$-Irradiation on the Dissemination of Microorganisms among Sea Fish in Bangladesh. EC Microbiology, 15(8), 784-794.

Anon. (2000). Kinetics of Microbial Inactivation for Alternative Food Processing Technologies Ultrasound. U.S. Food and Drug Administration Center for Food Safety and Applied Nutrition, http:// www.cfsan.fda.gov/ comm/ift-us.htmL.

Anon. (2003). Codex Alimentarius Commission. Report of the Thirty-Fifth Session of the Codex Committee on Food Hygiene. Alinorm 03/13A.Session of the Codex Committee on Food Hygiene.

Anon. (2004). Hygiene of foodstuffs. Regulation (EC) No. $852 / 2004$.

Anon. (2006). Guide to Minimize Microbial Food Safety Hazards of Fresh-cut Fruits and Vegetables, http:// www.cfsan.fda.gov/ dms/prodgui2.htmL.

APHA (American Public Health Association). (1998). Standard methods for the examination of water and wastewater. Washington, D.C., USA: APHA.

Balbani, A.P.S. and Montovani, J.C. (2008). Mobile phones: influence on auditory and vestibular Systems. Brazilian Journal of Otorhinolaryngol, 74 (1), 125-131. https://doi.org/10.1016/S1808-8694 (15)30762-X

Barnabas, J., Mamatha T.M. and Vidyaranya, V. (2011). Cell Population Reduction of Salmonella Typhimurium using Non-thermal Microwaves. International Journal of Genetic Engineering and Biotechnology, 2(3), 233-242.

Bauer, A.W., Kirby, W.M.M., Sherris, J.C. and Tierch, M. (1966). Antibiotic susceptibility testing by a standardized single disc method. American Journal of Clinical Pathology, 45(4), 493-496. https:// doi.org/10.1093/ajcp/45.4_ts.493
Bennett, J.W. and Klich, M. (2003). Mycotoxins. Clinical Microbiology Review, 16, 497-516. https:// doi.org/10.1128/CMR.16.3.497-516.2003

Canteón R. (2009). Antibiotic resistance genes from the environment: a perspective through newly identified antibiotic resistance mechanisms in the clinical setting. Clinical Microbiology Infection, 1(Suppl. 1), 20-25. https://doi.org/10.1111/j.14690691.2008.02679.x

Canumir, J.A., Celis, J.E., Brujin, J.D. and Vidal, L.V. 92002). Pasteurisation of Apple Juice by Using Microwaves. LWT-Food Science and Technology, 35 (5), 389-392. https://doi.org/10.1006/fst1.2001.0865

Cappuccino J.G. and Sherman N. (1996). Microbiology A laboratory manual. The Benjamin/Cummings Publishing Co., Inc., Menlo Park, California.

CDC (Centers for Disease Control and Prevention). (2014). Estimates of foodborne illness in the United States. Atlanta: CDC.

Cross, G. and Fung, D. (1982). The effect of microwaves on nutrient value of foods. Critical Review of Food Science and Nutrition, 16(4), 355-381. https:// doi.org/10.1080/10408398209527340

Dreyfuss, M.S. and Chipley, J.R. (1980). Comparison of effects of sublethal microwave radiation and conventional heating on the metabolic activity of Staphylococcus aureus. Applied and Environmental Microbiology, 39(1), 13-16.

Dutta, S., Hassan, M.R., Rahman, F., Jilani, M.F.A. and Noor, R. (2013). Study of antimicrobial susceptibility of clinically significant microorganisms isolated from selected areas of Dhaka, Bangladesh. Bangladesh Journal of Medical Science, 12(1), 34-42. https://doi.org/10.3329/ bjms.v12i1.13351

FAO (Food and Agriculture Organization of the United Nations). (2004). Worldwide regulations for mycotoxins in food and feed in 2003. Rome, Italy: FAO Food and Nutrition Paper.

Ferraro, M.J., Craig, W.A. and Dudley, M.N. (2011). Performance standards for antimicrobial susceptibility testing. Pennsylvania, USA: NCCLS.

FSANZ (Food Standards Australia New Zealand). (2001a). Guidelines for the microbiological examination of ready - to - eat foods. Retrieved October 18, 2014 from FSANZ website: http:// www.foodstandards.gov.au/publications/pages/ guidelinesformicrobi1306.aspx.

FSANZ. (Food Standards Australia New Zealand). (2001b). Microbiological Limits for Food with guidelines criteria. Retrieved October 18, 2014 from FSANZ website: http://www.foodstandards.gov.au/ publications/pages/guidelinesformicrobi1306.aspx.

Hossain, J., Islam, T., Feroz, F. and Acharjee, M. (2019). 
Evaluation of Antibiotic Resistant Bacteria from Pre and Post Microwave Oven Treated Burger Collected from Different Retailer in Dhaka City. IOSR Journal of Environmental Science, Toxicology and Food Technology (IOSR-JESTFT), 13(3), 15-19.

International Commission on Microbiological Specifications for food (ICMSF). (1986). Microorganisms in food sampling for microbiological analysis: Principle and specific application. $2^{\text {nd }}$ ed. USA: Blackwell Scientific Publication.

Jane, T.N., Tabassum, N. and Acharjee, M. (2018). Study on the existence of food born microflora and their drug resistant profile isolated from some fermented and non-fermented foods commonly available in Bangladesh. Bangladesh Journal of Microbiology, 8(1), 19-23. https://doi.org/10.3329/ sjm.v8i1.42433

Jeng, Y., Hu, J., Xiong, S. and Zhao, S. (2011). Effect of low-dose microwave radiation on Aspergillus parasiticus, Food Control, 22(7), 1078-1084. https:// doi.org/10.1016/j.foodcont.2011.01.004

Kakita, Y., Kashige, N., Murata, K., Kuroiwa, A., Funastu, M. and Watanabe, K. (1995). Inactivation of Lactobacillus bacteriophage PL-1 by microwave irradiation. Microbiology and Immunology, 39(8), 571-576. $\quad$ https://doi.org/10.1111/j.13480421.1995.tb02244.x

Kothari, V., Patadia, M. and Trivedi, N. (2011). Microwave sterilized media supports better microbial growth than autoclaved media. Research on Biotechnology, 2(5), 63-75.

Mead, P.S., Slutsker, L., Dietz, V., McCaig, L.F., Bresee, J.S., Shapiro, C., Griffin, P.M. and Tauxe, R.V. (1999). Food-related illness and death in the United States. Emerging Infectious Diseases, 5(5), 607-625. https://doi.org/10.3201/eid0505.990502

Munshi, S.K., Rahman, M.M. and Noor, R. (2012). Detection of virulence potential of diarrheagenic Escherichia coli isolated from surface water of rivers surrounding Dhaka city. Journal of Bangladesh Academy and Sciences, 36(2), 109-121. https:// doi.org/10.3329/jbas.v36i1.10927

Noor, R. (2013). Identification of drug-resistant bacteria among export quality shrimp samples in Bangladesh. Asian Journal of Microbiology Biotechnology and Environmental Science, 15(4), 31-36.

Nur, I.T., Mou, A.N. and Habiba, U. (2019). Comparative microbiological analysis of four different sea fishes collected from local market in Dhaka Metropolis. Food Research, 4(1), 161 - 165. https://doi.org/10.26656/fr.2017.4(1).253

Rahman, F. and Noor, R. (2012). Prevalence of pathogenic bacteria in common salad vegetables of
Dhakametropilis. Bangladesh Journal of Botany, 41

(2), 159-162. https://doi.org/10.3329/ bjb.v41i2.13442

Rosenberg, U. and Bogl, W. (1987). Microwave thawing, drying, and baking in the food industry. Food Technology, 41, 85-91.

Tamang, J.P., Shin, D.H., Jung, S.J. and Chae, S.W. (2016). Functional Properties of Microorganisms in Fermented Foods. Frontier in Microbiology, 7, 1-13. https://doi.org/10.3389/fmicb.2016.00578

Trivedi, N., Patadia, M. and Kothari, V. (2011). Biological Applications of Microwaves. International Journal of Life Science, 4(6), 37-46.

Wayland, J.R., Brannen, J.P. and Morris, M.E. (1977). On the interdependence of thermal and electromagnetic effects in the response of Bacillus subtilis spores to microwave exposure. Radiation Research, 71, 251-258. https:// doi.org/10.2307/3574726

Welt, B., Tong, C., Rossen, J. and Lund, D. (1994). Effect of microwave radiation on inactivation of Clostridium sporogenes (PA 3679) spores. Applied Journal of Environmental Microbiology, 60(2), 482488.

Woo, I.S., Rhee, I.-K. and Park, H.-D. (2000). Differential Damage in Bacterial Cells by Microwave Radiation on the Basis of Cell Wall Structure. Applied and Environmental Microbiology, 66(5), 2243-2247. https://doi.org/10.1128/ AEM.66.5.2243-2247.2000 